\title{
AN INTERACTION BETWEEN A JUVENILE CLYMENE DOLPHIN (STENELLA CLYMENE) AND SeIsmic survey vessel M/V Ramform Challenger -PGS, Bacia de SANTOS, BraziL
}

\author{
Michele F. Fernandes ${ }^{1, *}$, Andrea S. Cordeiro ${ }^{1}$, \\ Demetrio M. R. Carvalho ${ }^{1}$, Wilson R. Santos ${ }^{1}$ and Renata Ramos ${ }^{1}$
}

KeYwords: Stenella clymene, behavior, seismic survey, human impact, cetaceans.

Interactions between cetaceans and vessels have been widely reported. Various studies have reported the impacts of these interactions, in which researchers have been monitoring the effects of anthropogenic disturbance on these animals, such as collision, changes to behavior and on the social groups (Van Parijs and Corkeron, 2001; Lemon et al., 2005), separation between adults and young, abandonment of mating areas and even growing accustomed to living alongside humans, as in the case of one young Sotalia fluviatilis in Brazil (Santos, 19982). With respect to seismic surveys, aversion behavior by marine mammals in response to a seismic survey vessel has been specifically mentioned in several studies (e.g. Gould and Fish, 1998; Madsen et al., 2002; Stone and Tasker, 2006;
Gailey et al., 2007; Yazvenko et al., 2007, a;b).

Many vessels, at one time or another, have had dolphins around bowride the vessel, and it is quite common for these animals to associate with boats. Extreme cases have already been cited, such as a Risso's dolphin Grampus griseus ('Pelorus Jack'), who for 24 years, from 1888 to 1912, would often move in the bow-waves of steamers coming into New Zealand (Szabo, 1992 cited in Constantine and Baker, 1997).

On 22 July 2006, beginning at 08:07 hs, during seismic

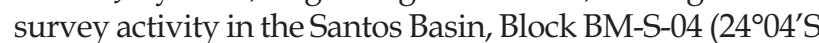
to $24^{\circ} 42^{\prime} \mathrm{S} / 43^{\circ} 21^{\prime} \mathrm{W}$ to $43^{\circ} 12^{\prime} \mathrm{W}$ ) (Figure 1), on board the ship M/V Ramform Challenger/PGS, a young clymene dolphin (Stenella clymene) was sighted (Figure 2). This

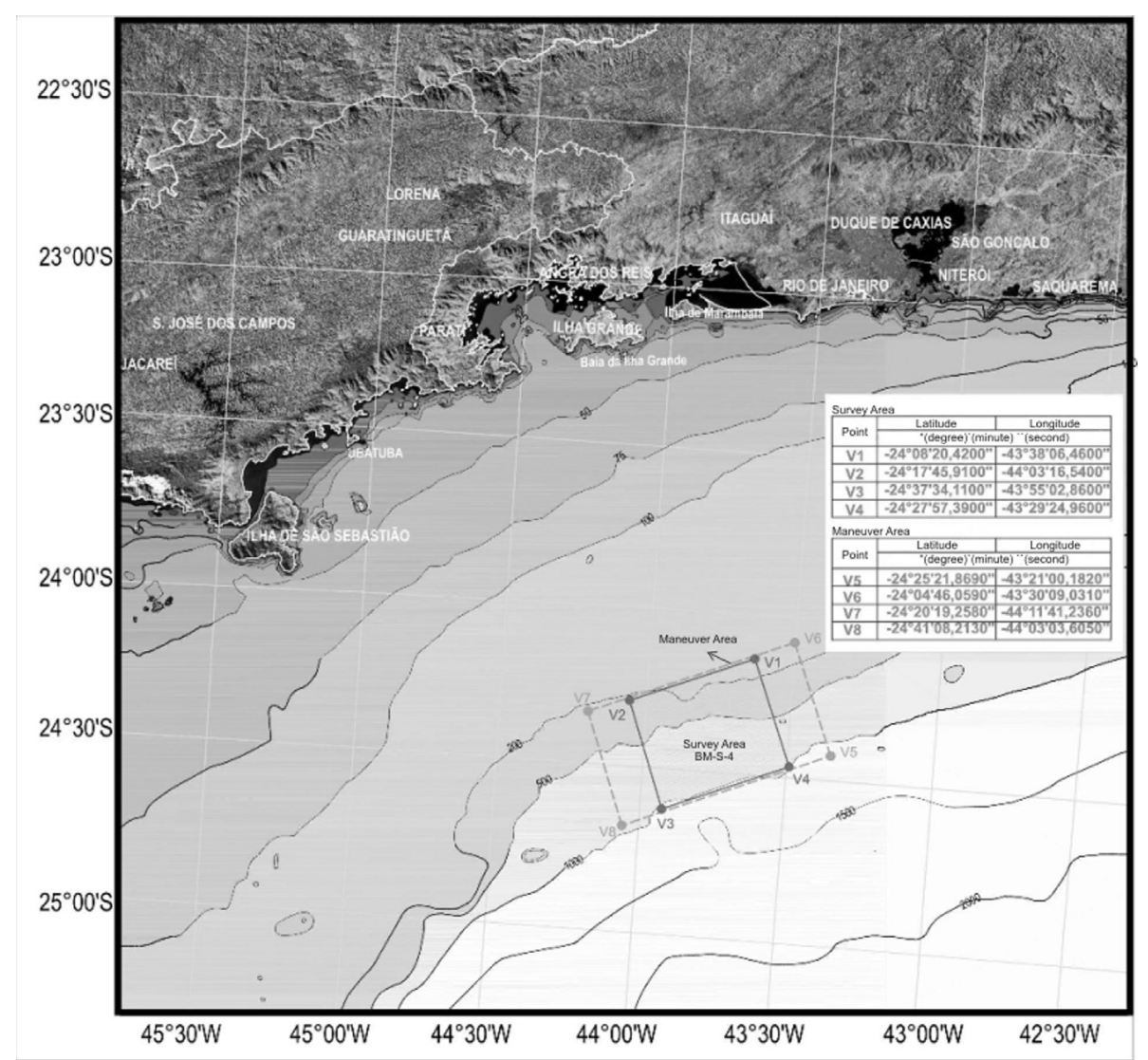

Figure 1. Map indicating the location of Block BM-S-04 in the Santos Basin, southeastern Brazil.

\footnotetext{
${ }^{1}$ Everest Tecnologia em Serviços Ltda. Av. João Batista Parra 633, 9th floor, Vitória, ES, 29052-123 Brazil.

* Corresponding author, e-mail: micheleffernandes@gmail.com.

2 Santos, M. C. O. (1998) Hand-feeding wild Sotalia: A new matter of concern in Brazil? In abstract, $8^{\circ}$ Reunião de Trabalhos de Especialistas em Mamíferos Aquáticos da América do Sul, Recife, Brasil.
} 


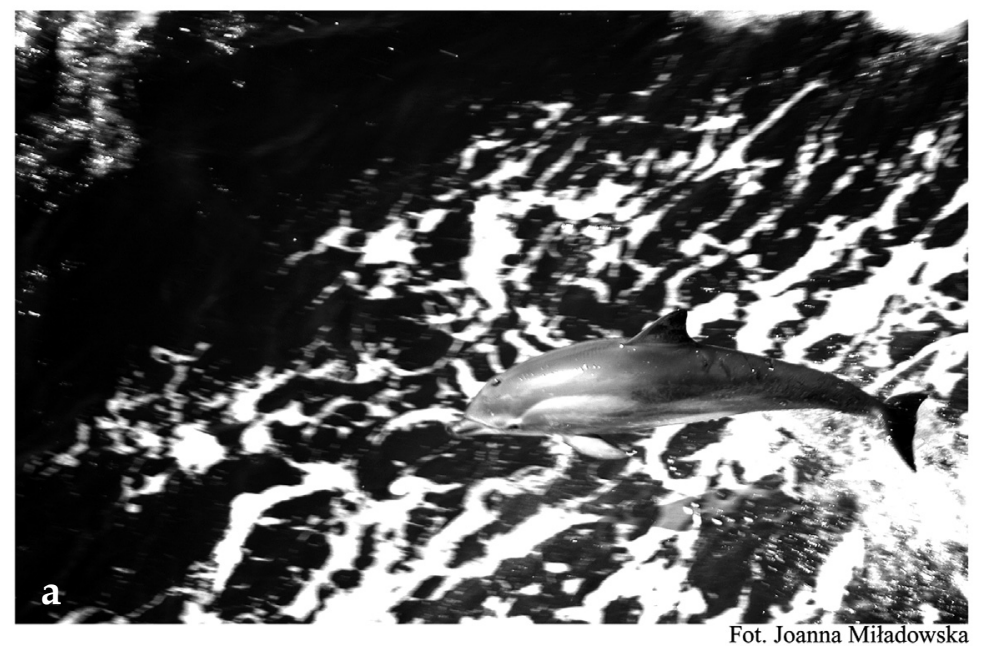

Figure 2. Juvenile clymene dolphin (S. clymene) sighted on 22 July 2006, while interacting with the seismic survey ship M/V Ramform Challenger PGS (Photo by Joanna Miladowska).

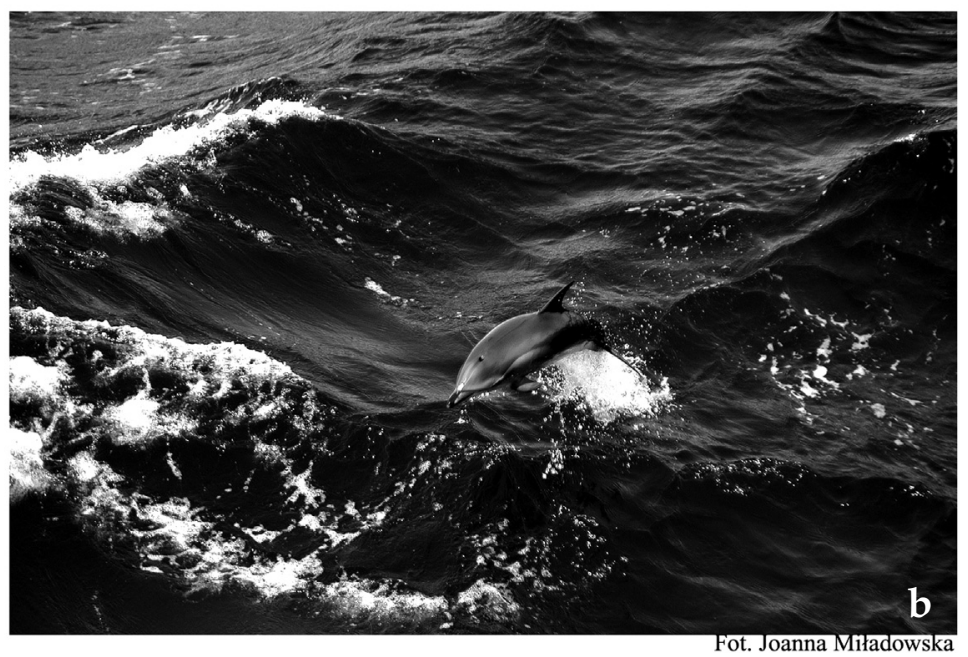

animal continued to accompany the vessel until 24 July 2006, totalizing some 56 hours.

The animal was alone and, throughout the period that the ship was in the area (27 days prior to the appearance of the dolphin, 51 days in total), no additional clymene dolphins were sighted. The animal was seen for the first time heading from stern to bow, to starboard, inside the seismic survey 'safety area'. The safety area is a $500 \mathrm{~m}$ radius zone around the seismic survey sound source (air guns) if in which, according to the 'Guide for Monitoring Marine Fauna in the Activity of Acquiring Seismic Data' (IBAMA, 2005), marine mammals or chelonians are sighted, seismic surveys must cease. Seismic survey activity should only resume, according to the guidelines, when these animals have left the safety zone and a 30 minute-period has elapsed without a sighting within a radius of $1000 \mathrm{~m}$ from the sound source (the 'Warning Area').

Seismic activity was curtailed immediately after observing the dolphin inside the safety area. The animal continued to accompany the ship until 24 July 2006, and seismic survey activity was not conducted throughout this period. Between the 23 and 24 July the dolphin strayed away from the ship (more than 1000m) and seismic survey activity was resumed on the morning of the 24 July. However, the animal came back to the safety area and the sound production was stopped again, with the airgun array staying silent for the entire day on 24 July. Joint action was set in motion, involving consultation between the onboard Marine Mammal Observer (MMO), the seismic party chief, the ship's Master, the coordinators of the Everest Program for Biota Monitoring and the PGS (Petroleum GeoService) Brazil Coordinator of Environmental Programs. The first step was to make contact with researchers specializing in marine mammals, to check what procedure could be applied in an unusual situation such as this, since the Brazilian legislation forbids any attempt to chase or remove animals near the seismic survey vessel (IBAMA, 2005).

One idea was to put the 'workboat' (support boat) into the water to attract and lead the dolphin away from the survey area. At $12: 27$ h on 24 July 2006, the first attempt to attract the animal with the workboat was made, with consent from CGPEG/IBAMA (the entity responsible for the Brazilian Environmental Legislation), and with one $\mathrm{MMO}$ on board. A rope 
wrapped in aluminum foil was hung in the water to act as a lure for the animal. This first attempt was met with no success, as the animal was evasive, always seeking to get on the opposite side of the workboat. Occasionally the juvenile dolphin did show interest in the lure from the workboat, but as soon as this was removed the animal lost interest and once again moved to the opposite side of the ship. At no time did the boat accelerate towards the animal to frighten it, but even when the workboat approached, the dolphin tended to swim in the opposite direction.

The animal remained within sight of the observers (workboat crew and the MMOs) the entire day, but with less aerial activity (fewer leaps) than previously observed and with periods of 'disappearance' (around 20 minutes). These increased when the workboat was in the water. Visual search for the animal was conducted from the starboard and port wings of the bridge, and also from the stern and the bow of the ship, to ensure that the dolphin had moved some distance away from the vessel. The three MMOs onboard took turns, with two MMOs searching on the port and starboard wings of the bridge, respectively, and a third one searching at the bow and stern, simultaneously.

After a long period of disappearance, now in the late afternoon $(16: 20 \mathrm{~h})$, the two support boats (the workboat and the FRC - Fast Rescue Craft) were placed in the water, one to port and the other to starboard, with an MMO always on board, in case the animal should re-appear. On board the seismic ship were the third MMO and the onboard oceanographer (responsible for the company's other environmental projects), positioned on the wings of the bridge, to continue monitoring. In addition to these on-board observers, the seismic party chief, the ship's master and radio operator were also present. The boats remained at a distance of some $300 \mathrm{~m}$ from the ship, both of them with a lure.

The animal was once again sighted at over $500 \mathrm{~m}$ from the seismic ship M/V Ramform Challenger. At this point, one of the support boats slowly approached the animal, and the dolphin followed the boat, probably as a result of the lure, and it was led towards the 'assistant vessel' Big John I (a vessel that remains at some 1-2 miles from the seismic vessel throughout the entire activity, assisting fishing boats, which was around one mile to starboard). The lure was handed over to a crew member of the assistant vessel, which headed to the distant area of Block BM-S-4, and was followed by the dolphin, which was not resighted by the survey vessel. Monitoring continued until it got dark, with searches astern and ahead of the ship, plus those to port/starboard, so that seismic surveying could continue.

During the three days of observation, the dolphin showed no obvious outward signs of illness, starvation or injury, and was highly active throughout (performing total and partial leaps and 'porpoising' behavior at the bow and stern of the ship). The animal did appear to be foraging as on more than one occasion it was seen to attack small shoals of fish.

The reasons for such an extended dolphin-seismic vessel association are unclear. On one occasion, when the juvenile dolphin was some distance from vessel, it performed several leaps and moved irregularly, then approached very closely to the vessel, practically up alongside the hull, as though it were, perhaps, fleeing from something and seeking protection from the vessels. Alternatively, the animal could also have approached the vessel to get into the 'acoustic shadow' of the ship thereby evading higher sound levels around the airgun array.

Stone and Tasker (2006) suggested that different taxonomic groups of cetaceans may adopt different strategies for responding to acoustic disturbance from seismic surveys; the slower moving mysticetes orient away from the vessel and increase their distance from the source but move away from the area completely while some small odontocetes move out of the immediate area, however such behavior was not observed in this study.

Over six years of monitoring marine biota during the seismic activities for PGS (between 2001-2006) in Brazil, some 20 species of cetaceans have been observed in the seismic survey area (Silva, 2003; Moreira et al., 2004³; Ramos et al., 2004'; Dafferner et al., 20055;

\footnotetext{
${ }^{3}$ Moreira, S., Fernandes, T., Erber, C., Alencastro, P., Silva, E.D., Rinaldi, G., Aragão, R., Figna, V. and Ramos, R. (2004) Ocorrência de cachalotes (Physeter macrocephalus) na costa do Brasil. Pages 160-161 in Abstract, 11 Reunión de Trabajo de Especialistas en Mamíferos Acuáticos de América del Sur y $4^{\circ}$ Congreso de la Sociedad Latinoamericana de Especialistas en Mamíferos Acuáticos. 11-17 de Septiembre, Quito, Ecuador.

${ }^{4}$ Ramos, R., Ribeiro, R., Moreira, S.C., Erber, C., Alencastro, P.M.R., Poletto, F.R., Silva, E.D., Fernandes, F., Bertoncini, A., Moraes, E., Venturotti, A, Figueiredo, L.D., Fortes, R.C., Grando, A.P., Figna, V.N.D., Rinaldi, G.C. and Aragão, R.X. (2004) Monitoramento da biota marinha em atividades petrolíferas: uma contribuição para o conhecimento da distribuição e ocorrência da fauna marinha. Page 414 in Abstract, Congresso Brasileiro de Oceanografia e XVI Semana Nacional de Oceanografia, 10 e 15 de outubro, UNIVALI, Itajaí, Santa Catarina.

${ }^{5}$ Dafferner, G., Barbosa, M.B., Freitas, R.H.A., Penteado, J.P.C., Alencastro, P.M.R., Fortes, R.C., Laitano, K.S., Figna, V.N., Grando, A.P., Santos Jr., W.R., Silva Ribeiro, C.C., Gerhardinger. L.C. and Ramos, R.M.A. (2005) Resultados do esforço de observação de cetáceos a bordo do navio sísmico Falcon Explorer durante as atividades nas Bacias de Campos e Santos (dez/04 a jun/05): uma abordagem descritiva. In Abstract, II Congresso Brasileiro de Oceanografia, 9 a 12 de outubro de 2005, Vitória, Espírito Santo.
} 
Erber et al., 2005, $\left.\mathrm{a}^{6} ; \mathrm{b}^{7}\right)$. This was the first instance of a prolonged interaction $(\sim 56 \mathrm{~h})$ between a dolphin and a seismic ship.

\section{Acknowledgments}

We thank biologist Cristiano Vilardo Nunes (CGPEC/ IBAMA), Professor Dr. Sheila Marino Simão (UFRJ), for use of the lure, biologists Dr. José Martins da Silva (Instituto Golfinho Rotador), and Dr. Salvatore Siciliano (Fundação Oswaldo Cruz), for identification of the dolphin to species level. We also thank veterinarian Milton Marcondes and biologist Marcos Rossi of Instituto Baleia Jubarte. PGS (Petroleum Geo-Service) gave us permission to disclose the data. We are indebted to the Coordinator of Environmental Procedures at PGS, Alexandre Bacellar Netto, plus the entire crew of the ship M/V Ramform Challenger, especially the seismic party chief, Esben Jettestad, Master Halvor Schia, radio operator Tony Ferreira dos Santos and crew members Old Drablos, Nigel Pardoe, Alex Townley, Dan Barrat, James de Long and Paul Jackson, who assisted our team on board the support boats (workboat and FRC). Joana Miladowska kindly allowed us to use the photographs she took during the sighting. This manuscript was greatly improved by the comments of Dr. Chris Parsons and an anonymous reviewer.

\section{References}

Constantine, R. AND BAKer, C.S. (1997) Monitoring the commercial swim-with-dolphin operations in the Bay of Islands, New Zealand. Science \& Research Series No. 104. Department of Conservation, Wellington, New Zealand. 54 pp.

Gailey, G., Würsig, B. And McDonald, T.L. (2007) Abundance, behaviour and movement patterns of western gray whales in relations to a 3-D seismic survey, Northeast Sakhalin Island, Russian.
Environmental Monitoring and Assessment 134(1-3): 75-91.

Gould, J.C. AND Fish, P.J. (1998) Broadband spectra of seismic survey air-gun emissions, with reference to dolphin auditory thresholds. Journal of the Acoustical Society of America 103: 2177-2184.

Lemon, M., Lynch, T.P., Cato, D.H. and Harcourt, R.G. (2005) Response of traveling bottlenose dolphins (Tursiops truncatus) to experimental approaches by a powerboat in Jervis Bay, New South Wales, Australia. Biological Conservation 127: 363-372.

Madsen, P.T., Mohl, B., Nielsen, B.K. And Wahlberg, M. (2002) Male sperm whale behaviour during exposures to distant seismic survey pulses. Aquatic Mammals 28(3): 231-240.

VAn Parijs, S.M And Corkeron, P.J. (2001) Boat traffic affects the acoustic behaviour of Pacific humpback dolphins, Sousa chinensis. Journal of the Marine Biological Association of the United Kingdom 81: 533-538.

Samuels, A., Bejder, L. And Heinrich, S. (2000) A review of the literature pertaining to swimming with wild dolphins. Report prepared for the Marine Mammal Commission, Washington, D.C. Contract Number T74463123. 57 pp.

SIlva, E.D. (2003) Ocorrência e distribuição de Mysticeti e Odontoceti (Cetacea) em bacias sedimentares da região sudeste do Brasil. MSc Thesis. Universidade Estadual Paulista Jaboticabal, SP, Brazil. 105 pp.

Stone, C.J. and Tasker, M.L. (2006) The effects of seismic survey airguns on cetaceans in UK waters. Journal of Cetacean Research and Management 8: 255-263.

Yazvenko, S.B., McDonald, T.L., Blokhin, S.A., Johnson, S.R., Melton, H.R., Newcomer, M.W., Nielson, R and Wainwright, P.W. (2007a) Feeding of western gray whales during a seismic survey near Sakhalin Island, Russian. Environmental Monitoring and Assessment 134(1-3): 93-106.

Yazvenko, S.B., McDonald, T.L., Blokhin, S.A., Johnson, S.R., Meier, S.K., Melton, H.R, Newcomer, M.W., Nielson, R., Vladimirov, V.L. and WainWright, P.W. (2007b). Distribution and abundance of western gray whales during a seismic survey near Sakhalin Island, Russia. Environmental Monitoring and Assessment 134(1-3): 45-73.

\footnotetext{
${ }^{6}$ Erber, C., Moreira, S. C., Fernandes, T., Poletto, F.R., Alencastro, P.M.R., Grando, A.P., Figna, V.N.D., Dafferner, G., Freitas, R.H.A., Carneiro, A.V., Miranda, C.M., Barbosa, M.B., Eliseire Jr., D., Almeida, A.N.F. and Ramos, R.M.A. (2005a). Avistagens de baleiapiloto, orca-pigméia, falsa-orca, orca e golfinho-de-Risso: dados inéditos para ampliar o conhecimento de espécies pouco conhecidas Page 85 in Abstract, III Congresso Brasileiro de Mastozoologia, 12 a 16 de outubro, Vitória, Espírito Santo.

${ }^{7}$ Erber, C., Moreira, S., Fernandes,T., Carneiro, A., Alencastro, P.; Poletto, F., Figueiredo,L., Fortes, R., Bertoncini, Á., Grando, A., Rinaldi, G., Figna, V., Silva, E., Moraes, E. and Ramos, R. (2005b) The monitoring of marine mammals onboard seismic vessels as tool for the knowledge of the distribution of the genus Stenella in the Brazilian coast. Page 68 in Abstract, 19th Annual Meeting of the Society for Conservation Biology, 15 a 19 de Julho, Brasília, DF.
} 